\title{
Erratum to: Can we create a Canadian Perioperative Anesthesia Clinical Trials Group? We review the first five years and glimpse into the future
}

\author{
Richard Hall, MD - Scott Beattie, MD, PhD · Hilary P. Grocott, MD • C. David Mazer, MD • \\ Alexis F. Turgeon, MD · André Denault, MD, PhD · Homer Yang, MD • Manoj M. Lalu, MD • \\ Ronald B. George, MD • Sonia Sampson, MD • Heather McDonald, MD • \\ members of the Canadian Perioperative Anesthesiology Clinical Trials Group (PACT) \\ Steering Committee*
}

Published online: 27 October 2016

(C) Canadian Anesthesiologists' Society 2016

\section{Erratum to: Can J Anesth/J Can Anesth (2016) 63:1215-1222 \\ DOI 10.1007/s12630-016-0719-6}

In the article entitled: "Can we create a Canadian Perioperative Anesthesia Clinical Trials Group? We review the first five years and glimpse into the future" published in the November 2016 issue of the Journal, Can J Anesth 2016; 63: 1215-1222, the text on page 1218, 2nd column, lines 3-4 of the first paragraph should read: "the Canadian Anesthesia Research Foundation (CARF)". The publisher apologizes most sincerely for this error.

The online version of the original article can be found under doi:10.1007/s12630-016-0719-6.

R. Hall, MD $(\varangle) \cdot$ R. B. George, MD

Queen Elizabeth II Health Sciences Centre, Dalhousie

University, Halifax, NS, Canada

e-mail: rihall@dal.ca

S. Beattie, MD, PhD

University of Toronto, Toronto, ON, Canada

H. P. Grocott, MD - H. McDonald, MD

University of Manitoba, Winnipeg, MB, Canada

C. D. Mazer, MD

St. Michael's Hospital, Toronto, ON, Canada

A. F. Turgeon, MD

Université Laval, Quebec City, QC, Canada

\author{
A. Denault, $\mathrm{MD}, \mathrm{PhD}$ \\ Université de Montréal, Montreal, QC, Canada \\ H. Yang, MD \\ University of Ottawa, Ottawa, ON, Canada \\ M. M. Lalu, MD \\ The Ottawa Hospital, Ottawa, ON, Canada \\ S. Sampson, MD \\ Memorial University, St. John's, NL, Canada
}

